Provided for non-commercial research and education use. Not for reproduction, distribution or commercial use.

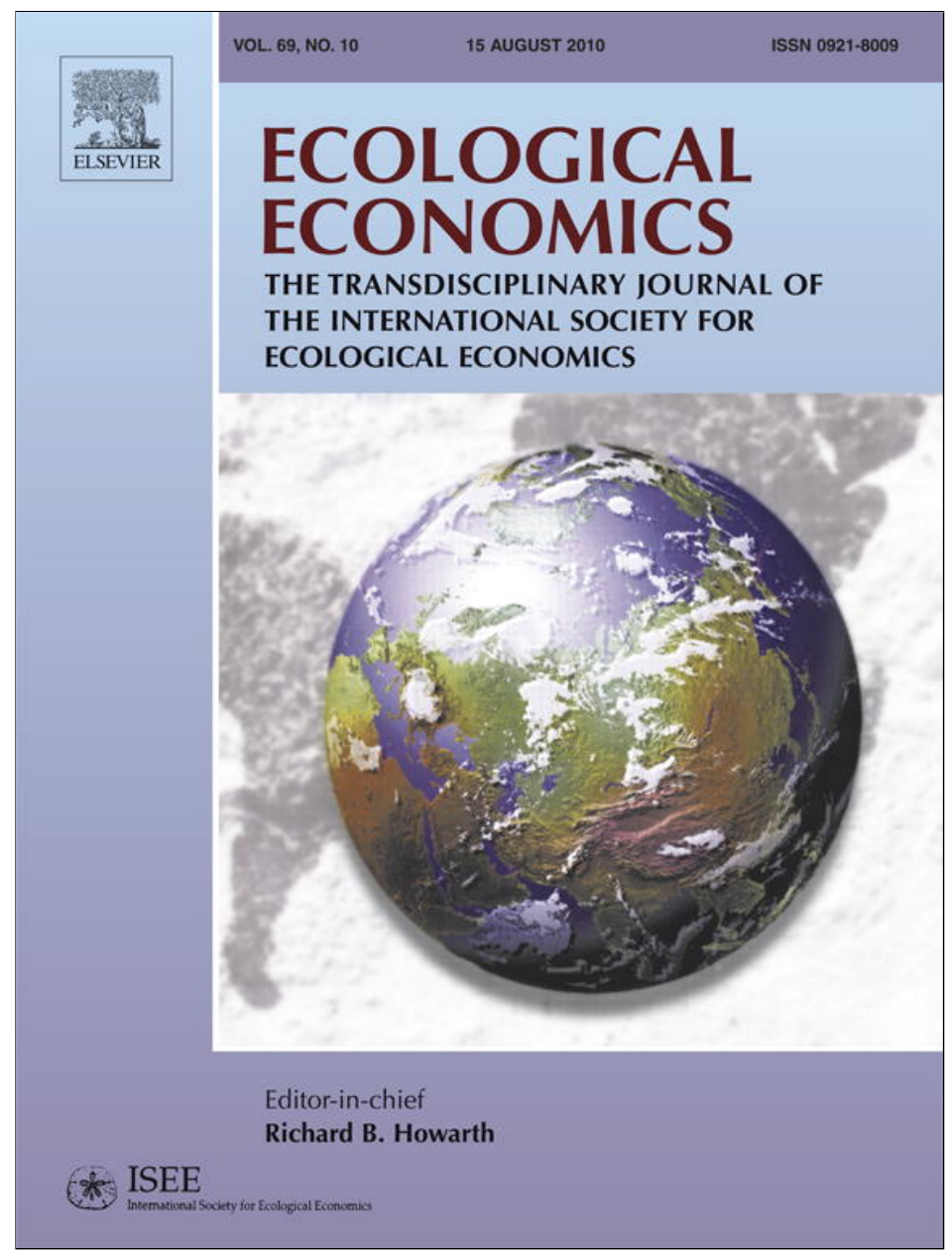

This article appeared in a journal published by Elsevier. The attached copy is furnished to the author for internal non-commercial research and education use, including for instruction at the authors institution and sharing with colleagues.

Other uses, including reproduction and distribution, or selling or licensing copies, or posting to personal, institutional or third party websites are prohibited.

In most cases authors are permitted to post their version of the article (e.g. in Word or Tex form) to their personal website or institutional repository. Authors requiring further information regarding Elsevier's archiving and manuscript policies are encouraged to visit:

http://www.elsevier.com/copyright 
Analysis

\title{
Sustainable governance of the agriculture and the Baltic Sea - Agricultural reforms, food production and curbed eutrophication
}

\author{
Markus Larsson $^{\mathrm{a}, \mathrm{b}, *}$, Artur Granstedt ${ }^{\mathrm{c}}$ \\ a Stockholm University, Stockholm Resilience Centre, SE-106 91 Stockholm, Sweden \\ ${ }^{\mathrm{b}}$ Mälardalen University, School of Business, Box 883, 72123 Västerås, Sweden \\ c The Biodynamic Research Institute, Skilleby, 15391 Järna, Sweden
}

\section{A R T I C L E I N F O}

\section{Article history:}

Received 28 January 2008

Received in revised form 4 May 2010

Accepted 4 May 2010

Available online 12 June 2010

\section{Keywords:}

Sustainable governance

Local production

Organic agriculture

Eutrophication

Baltic Sea

\begin{abstract}
A B S T R A C T
Agricultural production and nutrient loads to the Baltic Sea are likely to increase following Poland's and the Baltic States' entrance into the EU. According to HELCOM these trends will be highly dependent on the agricultural policies of the EU. The expansion of the EU can be seen as a window of opportunity where agricultural policy could improve the Baltic Sea environment.

Longstanding initiatives with local organic food systems and Ecological Recycling Agriculture (ERA) in the eight EU-countries in the Baltic Sea drainage area were evaluated during 2001-2004. The empirical results were scaled up to calculate environmental impact and food production for three different scenarios. In one scenario the Baltic Countries and Poland convert their agriculture following the average Swedish production. This resulted in $58 \%$ increase of nitrogen and $18 \%$ increase in phosphorus surplus, a corresponding increase in the load to the Baltic Sea and increased food production. In two other scenarios agriculture production in the whole Baltic Sea drainage area converts to ERA. This halved the nitrogen surplus from agriculture and eliminated the surplus of phosphorus. In these scenarios food production would decrease or remain stable depending on strategy chosen.
\end{abstract}

(c) 2010 Elsevier B.V. All rights reserved.

\section{Introduction}

Eutrophication is a major problem in the Baltic Sea. Since the 1900s, the Baltic Sea has changed from an oligotrophic clear-water sea into a eutrophic marine environment (HELCOM, 2007), a so called regime shift (Folke, 2006). The visible part of the eutrophication is the increase in algae. A more serious effect is the decrease in dissolved oxygen and the spreading of dead zones in coastal marine waters (Diaz and Rosenberg, 2008).

Excessive nitrogen and phosphorus loads coming from land-based sources, primarily agriculture, are the main causes of the eutrophication of the Baltic Sea (HELCOM, 2004a). Although some researchers focus more on phosphorus (e.g. Boesch et al., 2006) there is today, according to The Swedish Environmental Advisory Council (2005), "broad agreement that both phosphorus and nitrogen inputs should be reduced to alleviate eutrophication". Based on farm nutrient balance studies in Sweden and Finland Granstedt (2000) concluded that the main reason for the increased load of nitrogen and phosphorus from agriculture to the Baltic Sea is the specialization of agriculture with its separation of crop and animal production. This separation took place throughout the Scandinavian countries after

* Corresponding author. Stockholm University, Stockholm Resilience Centre, 10691 Stockholm, Sweden. Fax: + 4686747036.

E-mail address: markus.larsson@riksrevisionen.se (M. Larsson).
World War II. It increased after 1950 and culminated in the 1980s in Sweden, Finland and Denmark. The specialization was a consequence of an agriculture policy for structural rationalisation. This has resulted in farms with a high density of animals and great surpluses of plant nutrients, particularly in certain regions (Granstedt, 2000). During the same period more specialised forms of agriculture based on chemical fertilizers, non-renewable energy and pesticides use were introduced. Today about $80 \%$ of crop production is fodder for animals and the flow of nutrients have become linear: Input of artificial fertilizers to specialised crop farms, producing mainly fodder; selling fodder to specialised animal farms which also use input of imported concentrates like soy with high nitrogen content; accumulation of nutrients on the animal farms in the form of manure. Much more nutrients are accumulated than can be utilised in the farms' crop production and it is too costly to transport longer distances. Finally, the surplus of nitrogen and phosphorus risk polluting the environment (Granstedt, 2000). With the expansion of the European Union eight out of nine countries surrounding the Baltic Sea are members of the Union since 2004. Because agriculture production is expected to grow following the EU enlargement, nutrient reduction efforts should particularly address the impact of agriculture (HELCOM, 2005, p. 14). In the words of Diaz and Rosenberg (2008, p. 926); "The key to reducing dead zones will be to keep fertilizers on the land and out of the sea. For agricultural systems in general, methods need to be developed that close the nutrient cycle from soil to crop and back to agricultural soil". 
If this is not done, a dramatic increase in nutrient loads from Poland and the Baltic States is expected (HELCOM, 2004a, 2007).

Sweden, together with other countries, has agreed, through the Helsinki Commission (HELCOM), to participate in an effort to reduce the emissions of nutrients into marine ecosystems to sustainable levels (HELCOM, 2007). In accordance with the provisional nutrient reduction requirement Sweden shall reduce its loads of nitrogen and phosphorous to the Baltic Sea with between 21,000-17,000 and 290260 tons respectively, which will prove hard (SEPA, 2008). In a report from the Swedish Environmental Protection Agency and the Swedish Board of Agriculture the potential effects of different measures to reduce eutrophication are examined. A set of far reaching measures discussed would reduce the Swedish load to the Baltic Sea with 7000 tons of nitrogen and 61 tons of phosphorous (SEPA, 2008). The last few years have seen considerable reductions particularly in terms of emissions from sewage treatment plants and other point sources. Emissions from non-point sources have also fallen, primarily in eastern Germany, Poland and the Baltic States, countries which have reduced animal production and reduced the use of manure and chemical fertilizers (HELCOM, 2003a). The observed reductions in emissions have however not been large enough to improve the environmental state of the Baltic Sea (The Swedish Environmental Advisory Council, 2005). The new strategy, which is being jointly drafted by the HELCOM Member States, sets a target of achieving a good ecological status of the Baltic Sea by 2021 - a sea with diverse biological components functioning in balance and supporting a widerange of sustainable human economic and social activities (Brusendorff, 2007).

A reformed agricultural sector can limit the environmental degradation including the eutrophication of the Baltic Sea (SOU, 2005; The Swedish Environmental Advisory Council, 2005). For efforts to be cost-effective and have the largest effect they should be coordinated internationally (Boesch et al., 2006; HELCOM, 2005; Gren and Folmer, 2003). This paper draws on the results from two EU funded projects; BERAS (Baltic Ecologic Recycling Agriculture and Society) and GEMCONBIO (Governance and Ecosystem Management for the Conservation of Biodiversity). ${ }^{1}$

\subsection{Objectives}

The aim of this paper is to study how agricultural reforms can curb eutrophication of the Baltic Sea. To do this different scenarios on how the expansion of the EU affects the agriculture and the environment of the Baltic Sea are used. A scenario where Poland and the Baltic States convert their agriculture according to Swedish/Finnish agriculture of today is compared to a more hypothetical development where the agriculture around the Baltic Sea is converted to local organic production.

The environmental effects and output of the average agriculture of today and of local organic production are estimated from existing statistics and field trials. These results are used to build the three scenarios described above. The performance of the different scenarios and today's agriculture is compared and analyzed in terms of effects on production, the surrounding environment, employment, socio-economic effects and international cooperation before conclusions are drawn.

\section{Method}

\subsection{Principles of Ecological Recycling Agriculture Systems}

Ecological Recycling Agriculture (ERA) is a local organic agriculture system based on local and renewable resources. ERA produces food and

\footnotetext{
${ }^{1}$ See www.jdb.se/beras and www.gemconbio.eu.
}

other agriculture products according to the following basic ecological principles (Granstedt, 2005):

1. Protection of biodiversity.

2. Use of renewable energy.

3. Recycling of plant nutrients.

In consequence with these principles an ERA farm is defined as an organic (ecological) managed farm according the ifoam standards ${ }^{2}$ with no use of neither pesticides nor artificial fertilizers (ifoam principles 1 and 2) and with the additional condition of a high rate of recycling of nutrients based on organic, integrated crop and animal production. A higher degree of internal recycling within the system enables reduced external input of nitrogen. Nitrogen requirements are covered through biological nitrogen fixation of mainly clover/ grass leys. There is only a limited deficit of phosphorus and potassium in the input and output balance according to previous studies (Granstedt, 2000). The greater part of the minerals is recycled within the farm in the manure. The limited net export of phosphorus and other nutrients seems to be compensated by the withering processes in most soils and a recycling of food residues could further decrease these losses from the system (Granstedt, 2000). The strive to be selfsufficient in fodder limits the number of animals per hectare. In reality, however, some smaller amounts of imported inputs (seeds and fodder) can be necessary depending on variation in yield level between different years. An external fodder rate of a maximum of $15 \%$ of total fodder and an animal density $<0.75$ animal units/ha were used as criteria for selecting ERA-farms (Granstedt, 2005). ${ }^{3}$ By following these principles nutrient in manure does not exceed what can be utilised by crops during the crop rotation in the same system. Each single farm does not need to function as a closed system. Farms in the same region with complementing production could cooperate and together function as a recycling farming system in terms of fodder and manure, but regional specialisation of production is problematic. The studies are based on calculated surplus and emissions of reactive nitrogen and surplus of phosphorus compounds from the agriculturesociety system according to methods developed by Granstedt (1995; 2000; 2005).

\subsection{Comparison Between Farming Systems}

A total of 42 farms in the EU countries within the Baltic Sea drainage area were selected in a bottom up process in each country in order to monitor and evaluate their potential to reduce nutrient surplus and losses. The 42 test-farms are representative for the main agricultural conditions and drainage regions in the area (Fig. 1). The number of studied farms varied from 12 in Sweden to two in Germany. Russia is the only Baltic Sea country not included in this study. The plant nutrient balances carried out at the 42 ERA-farms gave information about the potential risk for leaching nitrogen and phosphorous and the potential risk of nitrogen emissions to the atmosphere, assuming a steady state in the soil over a longer period of time (Granstedt et al., 2008). This was then compared to existing data averages for conventional agriculture.

Swedish farming is regulated e.g. through environmental legislation which often are more strict than in other countries (SEPA, 2008). This includes environmental taxes on fertilizers and how nutrients are handled. There are e.g. restrictions on animal density, when spreading of manure is allowed, and requirements for how to store manure in a manner that minimize the loss of nutrients. Even so, the environmental performance between different farms varies significantly. The set of average data used includes production ranging from small to large and industrial to organic agriculture, the latter being a small

\footnotetext{
${ }^{2}$ International Federation of Organic Agriculture Movements. The standards are described at www.ifoam.org.

${ }^{3}$ An animal unit (au) is defined as one dairy cow, or two young cows, or three sows, or ten fattening pigs or 100 hens.
} 


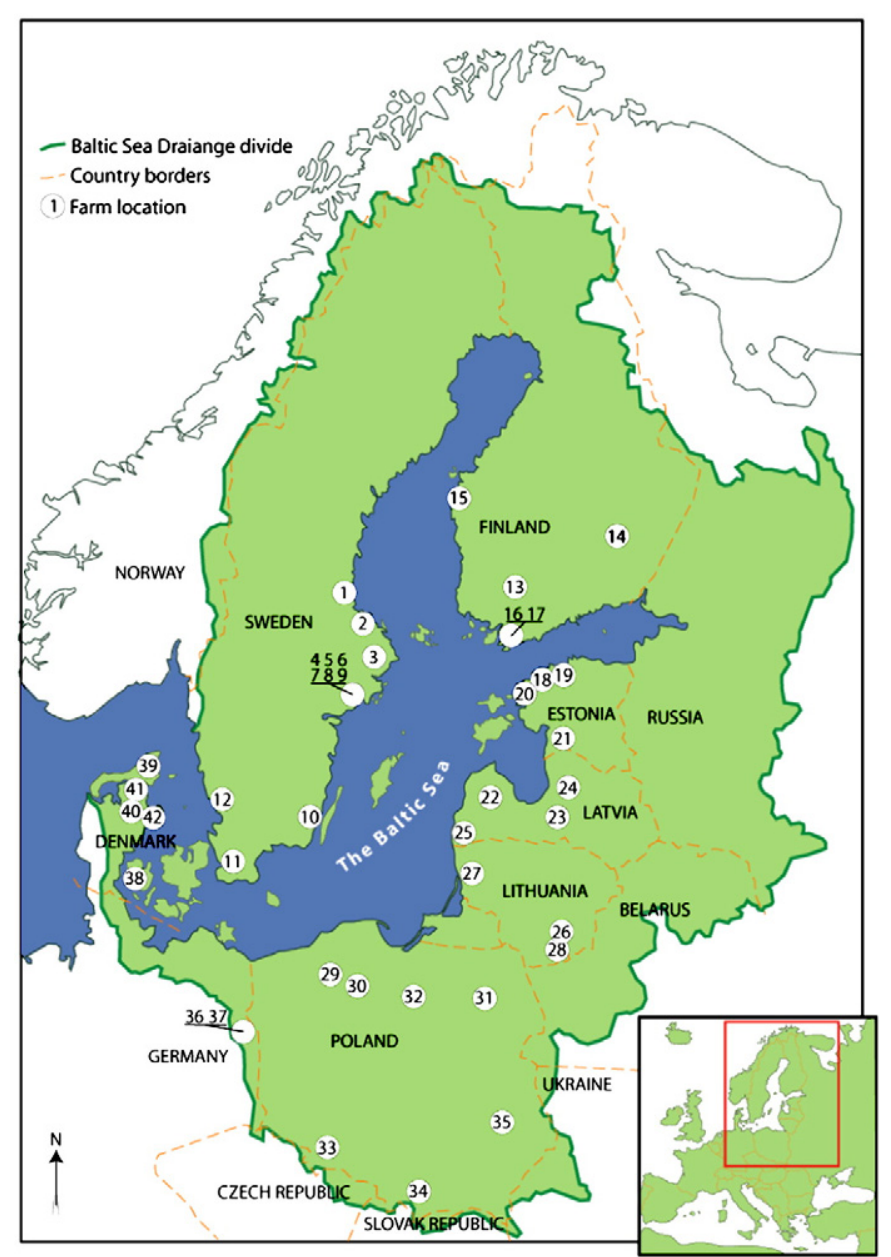

Fig. 1. The Baltic Sea drainage basin with locations of farms included in the study.

fraction of Swedish average agriculture. In comparing ERA with average data we eliminate the risk of focusing on extreme cases.

The principal difference between conventional agriculture and ERA at a regional system level is the degree of integration of crop and animal production on the farm. In conventional agriculture crop and animal production are more or less separated between different groups of farms which in addition often are concentrated in different regions, see Fig. 2 a. The conventional farming has been compared with the more integrated ERA. The same average animal density for all the farms is used and human consumption of both animal and vegetable agricultural products according to the average food consumption is assumed with one important difference. The meat consumption will, to a higher degree, be based on meat from ruminants compared with the conventional consumption which is more based on pig and poultry meat. The reason is a higher share of clover grass ley in ecological agriculture.

\subsection{Field and Farm Gate Balances}

The methods for calculating nutrient flows within the farming systems and nutrient balances follow those described in studies by Granstedt (1995; 2000), Cederberg and Flysjö (2004), Halberg et al. (2000), Kristensen et al. (2005), Steinshamn et al. (2004) and Statistics Sweden (SCB, 2003a). In these studies the nutrient surplus is defined as the difference between input and output of nutrients into the system. This difference can be calculated based on nutrient balances for the farm as a whole (farm gate balance) or at field level (field balance $=$ soil surface balance). In this type of emission-related
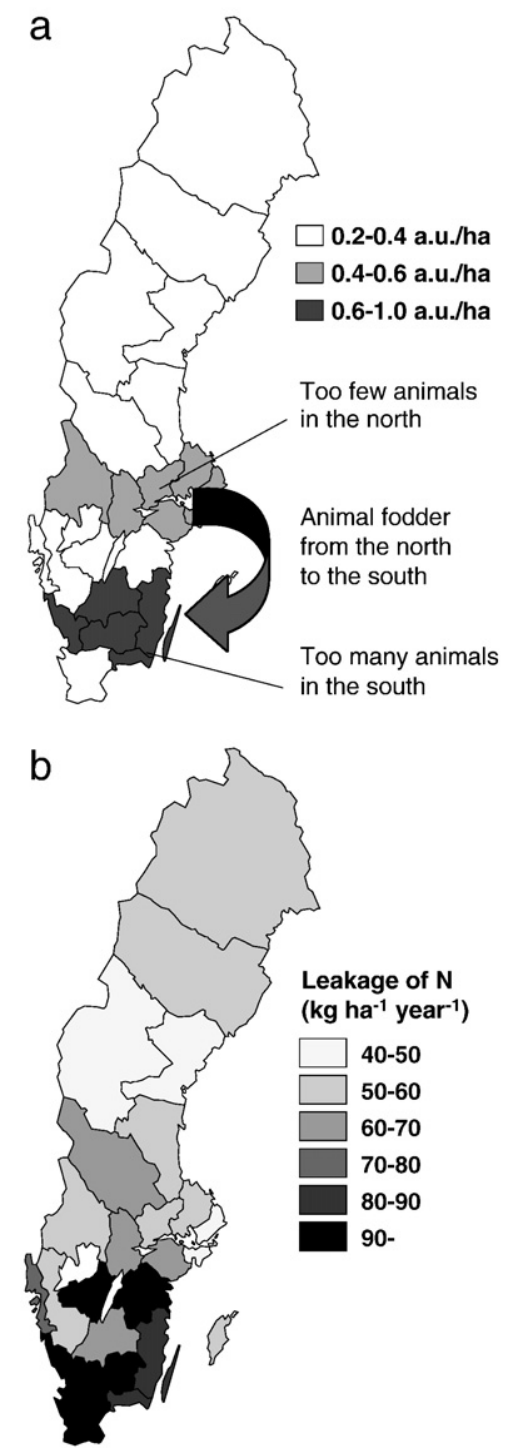

Fig. 2. a. Swedish counties grouped according to intensity of animal production. 1 animal unit (au) equals one dairy cow, or two young cows, or three sows, or ten fattening pigs or 100 hens. b. Levels of nitrogen $(\mathrm{N})$ leaching into the water in different parts of Sweden measured as kg N per hectare and year. Modified from Granstedt, 2000.

studies with a focus on the total pollution of nitrogen within the Baltic Sea drainage area the focus must be on leaching per hectare of agricultural land. This is in accordance with the regional life cycle assessment presented by Geier and Köpke (1998) and the recommendations of Payraudeau and van der Werf (2005).

The difference between farm gate and field surplus of nitrogen at farm level corresponds to the ammonia emissions from the animals and their exudates (manure and urine) before application of manure and urine on fields. Nitrogen and phosphorus losses were calculated for ERA farms and conventional production using data from Statistics Sweden (SCB, 2003b, 2004, 2005). The results are scaled up to construct three hypothetical scenarios for the involved countries compared to the actual situation of today. One scenario with conventional agriculture where the Baltic countries and Poland convert their agriculture sector into the same structure and use of resources as Sweden and Finland, a scenario where agricultural production in each country converts to ERA methods following the studied farms in the respective countries (ERA Scenario 1), and one scenario where all agriculture in the Baltic Sea drainage area converts to ERA methods as practiced in Sweden (ERA scenario 2). 
Table 1

Nitrate and phosphorus emissions from point and non-point sources including the natural background load into the Baltic Sea from its drainage area for the year 2000 . Emission per capita refers to people in the drainage area of the Baltic Sea. Th background load is, on average, $30 \%$ of total emissions. All countries except for Russia are included in the present study.

\begin{tabular}{|c|c|c|c|c|c|c|c|}
\hline Country & $\begin{array}{l}\text { Drainage } \\
\text { area } \mathrm{km}^{2 \mathrm{a}}\end{array}$ & $\begin{array}{l}\text { Kilotons } \\
\text { N/year }\end{array}$ & $\begin{array}{l}\% \text { of } \\
\text { total }^{\mathrm{b}}\end{array}$ & $\begin{array}{l}\mathrm{kg} / \text { capita } \\
\text { year }^{-1 \mathrm{c}}\end{array}$ & $\begin{array}{l}\text { Kilotons } \\
\text { P/year }\end{array}$ & $\begin{array}{l}\% \text { of } \\
\text { total }^{\mathrm{b}}\end{array}$ & $\begin{array}{l}\mathrm{kg} / \text { capita }^{-1 \mathrm{c}} \\
\text { year }^{-1 \mathrm{c}}\end{array}$ \\
\hline Denmark & 31,110 & 62 & 8 & 13.8 & 1.5 & 4 & 0.3 \\
\hline Estonia & 44,000 & 33 & 4 & 21.0 & 1.4 & 3 & 0.9 \\
\hline Finland & 301,300 & 147 & 18 & 29.0 & 6.8 & 16 & 1.4 \\
\hline Germany & 28,600 & 32 & 4 & 10.2 & 1.2 & 3 & 0.4 \\
\hline Latvia & 64,600 & 54 & 7 & 20.2 & 1.5 & 4 & 0.6 \\
\hline Lithuania & 54,160 & 36 & 4 & 9.6 & 0.8 & 2 & 0.2 \\
\hline Poland & 311,900 & 230 & 28 & 6.0 & 18.7 & 45 & 0.5 \\
\hline Russia & 314,800 & 54 & 7 & 5.3 & 2.5 & 6 & 0.2 \\
\hline Sweden & 440,040 & 176 & 21 & 20.6 & 6.8 & 17 & 0.8 \\
\hline Total & $1,590,510$ & 822 & 100 & 10.6 & 41.2 & 100 & 0.5 \\
\hline
\end{tabular}

a $\operatorname{HELCOM}(2004 \mathrm{a}, \mathrm{b})$.

b HELCOM (2005).

c HELCOM (2003a).

\section{Results - The Influence of Production Systems}

\subsection{Present State - Nitrogen and Phosphorus Loads in the Baltic Sea Drainage Area}

The contribution of each country to the total flow of nitrogen and phosphorus to the Baltic Sea is shown in Table 1. Poland contributes the most nitrogen and phosphorus flowing into the Baltic Sea, followed by Sweden and Finland. However, measured as emission per capita the Swedish contribution is three times as high for nitrogen and almost twice as high for phosphorus compared to Poland's contribution. Finnish per capita emissions are even higher.

Total nitrogen input to surface waters within the Baltic Sea drainage area was 822 kilotons in the year 2000. In Sweden about $60 \%$ of the total nitrogen load to the Baltic Sea is anthropogenic and about half of the anthropogenic load originates from agriculture (Brandt and Ejhed, 2002). The distribution of sources differs slightly between countries but the pattern is similar. On average agriculture is responsible for about half of the nutrients from anthropogenic sources deposited in the Baltic Sea by the surrounding countries (HELCOM, 2003b). Surplus in agriculture, measured as kg/ha, was highest in Denmark, Sweden and Finland. The nitrogen surplus of the three Nordic countries by far exceeded that of Estonia, Latvia and Lithuania, Table 2. The surplus is measured as the difference between import and export from the agriculture and a part of that contributes to the nutrient load to the Baltic Sea.

Agricultural input of nitrogen and phosphorus, in the form of artificial fertilizers, drastically increased during the second half of the 20th century. Output increased as well, but since only one third of the input of nitrogen is exported from the system in the form of food products such as milk, meat and bread grain, surplus of nutrients also increased (Granstedt, 2000; Granstedt et al., 2004).

The levels of nutrient leakage are also affected by the geographical division of animal production. Fig. 2a shows a high concentration of animal production in southern Sweden with a lower concentration in the rest of the country. Together with extensive imports of concentrated fodder (Deutsch, 2004), fodder bought from specialised crop farms and an additional use of artificial fertilizer a surplus of plant nutrients in the form of manure is found in southern Sweden. This part of the country also exhibits the most favourable conditions for leaching of nutrients in terms of soil texture and climate. Fig. $2 \mathrm{~b}$ illustrates the leakage of nitrate into the water in different parts of Sweden. Regions with the highest levels of leakage also have high densities of animal production.

\subsection{Results from Nutrient Balance Studies}

The average nitrogen surplus on the studied 12 Swedish ERA-farms was $36 \mathrm{~kg} \mathrm{~N} / \mathrm{ha}$ and year during 2002-2004. This can be compared to the average for Swedish agriculture which has been calculated to $79 \mathrm{~kg} / \mathrm{ha}$ and year for 2000-2002. Some variation between the selected Swedish ERA farms was observed. This was related to the animal density with a lower $\mathrm{N}$-surplus on farms with low animal density than on farms with a higher animal density. Nitrogen and phosphorus surpluses and calculated ammonia losses for all involved countries are presented in Table 2. The average nitrogen and phosphorus surplus in average agriculture was 56 and $11 \mathrm{~kg} /$ ha respectively in the studied countries in 2000. On the selected ERA-farms, the average observed nitrogen surplus was $32 \%$ lower, i.e. $38 \mathrm{~kg} \mathrm{~N} / \mathrm{ha}$. Based on these figures the field surplus has been calculated, see Table 3 . The calculated $\mathrm{N}$ field surplus was $38 \mathrm{~kg} \mathrm{~N} /$ ha for average agriculture and 47\% lower on ERA farms, i.e. $20 \mathrm{~kg} \mathrm{~N} / \mathrm{ha}$. The phosphorus surplus was eliminated in total. In fact a net deficit of $1 \mathrm{~kg} /$ ha was observed.

Field balances, i.e. input-output, for the ERA-farms have been calculated based on the data collected. Ammonia $\left(\mathrm{NH}_{4}\right)$ losses is assumed to be the same on average Swedish farms and ERA farms if they both have the same animal density ( $0.6 \mathrm{au} / \mathrm{ha})$ and similar techniques for manure management. The calculations have been made with two alternative levels of $\mathrm{NH}_{4}$ emissions from the animal production and manure management. In both conventional and ERA agriculture an estimated $30-40 \%$ of the nitrogen in animal exudates is lost as $\mathrm{NH}_{4}$ to the atmosphere.

\subsection{Nitrogen Surplus Under Different Assumptions}

Assuming that $40 \%$ of the nitrogen in animal exudates is lost as $\mathrm{NH}_{4}$ to the atmosphere the average field surplus on ERA-farms, calculated as the difference between the farm gate balance surplus ( $36 \mathrm{~kg} \mathrm{~N} / \mathrm{ha}$ ) and ammonic losses ( $22 \mathrm{~kg} \mathrm{~N} / \mathrm{ha}$ ) is $14 \mathrm{~kg} \mathrm{~N} / \mathrm{ha} \mathrm{(7+7} \mathrm{in} \mathrm{Fig.} \mathrm{3)} \mathrm{compared} \mathrm{to}$ $57 \mathrm{~kg} \mathrm{~N} / \mathrm{ha}(28+29)$ for the average field surplus of Swedish agriculture. Nitrate leaching is assumed to be equal to the nitrogen

Table 2

Arable land (million hectare, Mha) and calculated total farm gate surplus of $\mathrm{N}$ and $\mathrm{P}$ and ammonia losses (40\%), in kilo per hectare (kg/ha) and kilotons per year (kt/a), in average agriculture and ERA-farms.

\begin{tabular}{|c|c|c|c|c|c|c|c|c|c|c|c|c|c|}
\hline & \multirow{3}{*}{$\begin{array}{l}\text { Arable land }^{a} \\
\text { Mha }\end{array}$} & \multicolumn{6}{|c|}{ Average agriculture } & \multicolumn{6}{|c|}{ ERA agriculture } \\
\hline & & \multicolumn{2}{|c|}{$\mathrm{N}$ surplus } & \multicolumn{2}{|c|}{ P surplus } & \multicolumn{2}{|c|}{$\mathrm{NH}_{4}$ loss } & \multicolumn{2}{|c|}{$\mathrm{N}$ surplus } & \multicolumn{2}{|c|}{ P surplus } & \multicolumn{2}{|c|}{$\mathrm{NH}_{4}$ loss } \\
\hline & & $\mathrm{kg} / \mathrm{ha}$ & $\mathrm{kt} / \mathrm{a}$ & $\mathrm{kg} / \mathrm{ha}$ & $\mathrm{kt} / \mathrm{a}$ & $\mathrm{kg} / \mathrm{ha}$ & $\mathrm{kt} / \mathrm{a}$ & $\mathrm{kg} / \mathrm{ha}$ & $\mathrm{kt} / \mathrm{a}$ & $\mathrm{kg} / \mathrm{ha}$ & $\mathrm{kt} / \mathrm{a}$ & $\mathrm{kg} / \mathrm{ha}$ & $\mathrm{kt} / \mathrm{a}$ \\
\hline Sweden & 2698 & 79 & 184 & 3 & 8.1 & 22 & 58 & 36 & 97 & -2 & -5.4 & 21 & 57 \\
\hline Finland & 2387 & 75 & 179 & 7 & 16.7 & 14 & 33 & 38 & 91 & 3 & 7.2 & 18 & 43 \\
\hline Est/Lat/Lith & 7513 & 19 & 141 & 3 & 21.4 & 16 & 117 & 41 & 308 & -1 & -3.8 & 12 & 99 \\
\hline Poland & 14,247 & 57 & 812 & 19 & 270.7 & 15 & 217 & 32 & 456 & -2 & -28.5 & 16 & 233 \\
\hline Germany & 2051 & 74 & 152 & -2 & -4.1 & 9 & 19 & 16 & 33 & -3 & -6.2 & 6 & 13 \\
\hline Denmark & 2077 & 129 & 268 & 8 & 16.6 & 54 & 112 & 87 & 181 & 5 & 9.3 & 49 & 103 \\
\hline Total & 30973 & 56 & 1736 & 11 & 329.4 & 18 & 556 & 38 & 1165 & -1 & -27.3 & 18 & 548 \\
\hline
\end{tabular}

a Land in the Baltic Sea drainage area only. 
Table 3

Calculated field surplus of nitrogen and phosphorus.

\begin{tabular}{|c|c|c|c|c|c|c|c|c|}
\hline & \multicolumn{4}{|c|}{ Average agriculture } & \multicolumn{4}{|c|}{ ERA agriculture } \\
\hline & \multicolumn{2}{|c|}{$\mathrm{N}$ surplus } & \multicolumn{2}{|c|}{ P surplus } & \multicolumn{2}{|c|}{$\mathrm{N}$ surplus } & \multicolumn{2}{|c|}{ P surplus } \\
\hline & $\mathrm{kg} / \mathrm{ha}$ & $\mathrm{kt} / \mathrm{a}$ & $\mathrm{Kg} / \mathrm{ha}$ & $\mathrm{kt} / \mathrm{a}$ & $\mathrm{kg} / \mathrm{ha}$ & $\mathrm{kt} / \mathrm{a}$ & $\mathrm{kg} / \mathrm{ha}$ & $\mathrm{kt} / \mathrm{a}$ \\
\hline Field surplus & 38 & 1180 & 11 & 329 & 20 & 618 & -1 & -27.3 \\
\hline
\end{tabular}

surplus minus ammonia losses, denitrification and net change in soil $\mathrm{N}$ status according to Dalgaard et al. (2006) and Kristensen et al. (2005). Using calculations of average drainage leakage in Swedish agriculture (Brandt and Ejhed, 2002) and additional leakage to ground water (Brink, 1990) an average of $45 \%$ of the calculated field surplus of $57 \mathrm{~kg} \mathrm{~N} / \mathrm{ha}$ and year in Swedish agriculture is lost in field leakage. This equals a field leakage of $28 \mathrm{~kg} / \mathrm{ha}$. For Swedish ERA farms this corresponds to a theoretical nitrogen leakage of $7 \mathrm{~kg} / \mathrm{ha}$ and year. This gives a reduction of $75 \%$ nitrogen leaching on ERA farms compared to an average Swedish farm.

Assuming a $30 \% \mathrm{NH}_{4}$ loss gave a field balance $\mathrm{N}$-surplus of $20 \mathrm{~kg} / \mathrm{ha}$ $(9+11$ in Fig. 3$)$ for ERA. This can be compared with the calculations for the average of all Swedish agriculture that were based on the same assumptions and that gave a field level N-surplus of $63(30+33) \mathrm{kg} / \mathrm{ha}$. The calculated leaching was $9 \mathrm{~kg} / \mathrm{ha}$ in ERA and $30 \mathrm{~kg} / \mathrm{ha}$ in conventional agriculture, a reduction with $70 \%$.

To understand the differences between individual farms and between farming systems it is important to take into consideration possible variations in nutrient content in agricultural products as well as possibilities for an under or over estimation of nitrogen fixation (Kristensen, 2002). Increasing the average nitrogen fixation by $25 \%$ on the 12 Swedish ERA farms increases the average surplus by $33 \%$ to $47 \mathrm{~kg}$ $\mathrm{N} / \mathrm{ha}$ and decreases the difference between the ERA farms and the average conventional agriculture from 43 to $32 \mathrm{~kg} \mathrm{~N} / \mathrm{ha}$, see Table 4 . A decrease of nitrogen fixation by $25 \%$ decreases the surplus by $33 \%$ to $24 \mathrm{~kg} \mathrm{~N} / \mathrm{ha}$ and increases the difference to $55 \mathrm{~kg} \mathrm{~N} / \mathrm{ha}$ (Granstedt et al., 2008).

\subsection{Scenarios on Nitrogen and Phosphorus Emissions and Production}

Based on the results of the 42 studied farms in the eight EU countries presented in Table 2 different scenarios have been developed. In one fully realistic scenario Poland and the Baltic countries change their agriculture towards the conventional production methods used in Sweden today. Two other, less likely, scenarios assume the conversion of agriculture in the whole Baltic Sea drainage area to a less intensive ERAtype agriculture.

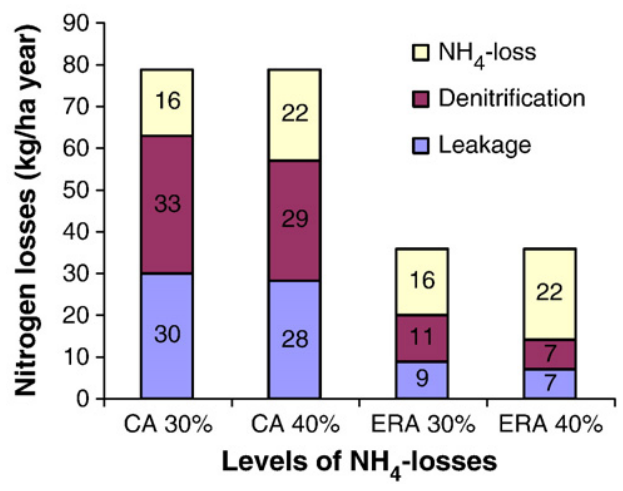

Fig. 3. The distribution of $\mathrm{N}$ in the calculated $\mathrm{N}$-surplus for average Swedish agriculture (CA) and the ERA-farms with two different manure handling systems (resulting in 30 and $40 \%$ ammonia losses from the total animal exudates respectively) and estimated leaching calculated as, on average, $45 \%$ of the surplus in the field balance.
Table 4

Nitrogen farm gate surplus in ERA under different assumptions on nitrogen fixation.

\begin{tabular}{llll}
\hline & $\begin{array}{l}\text { ERA average } \\
\mathrm{N}, \mathrm{kg} / \mathrm{ha}\end{array}$ & $\begin{array}{l}\text { High N fixation } \\
(+25 \%)\end{array}$ & $\begin{array}{l}\text { Low N fixation } \\
(-25 \%)\end{array}$ \\
\hline N surplus ERA & 36 & 47 & 24 \\
$\begin{array}{c}\text { Difference between average } \\
\text { agriculture and ERA }\end{array}$ & 43 & 32 & 55 \\
\hline
\end{tabular}

a Calculated as total farm gate surplus of $\mathrm{N}$ in average agriculture $(79 \mathrm{~kg} / \mathrm{ha})-\mathrm{N}$ surplus ERA under different assumptions.

The conventional scenario was calculated to result in a $58 \%$ increase of the nitrogen surplus in the field balance and a corresponding increase in the load to the Baltic Sea. Most likely there would also be an increase of the surplus of phosphorus and a corresponding increase in phosphorus load. In a HELCOM (2007) scenario, called Business as usual in agriculture, where the agricultural sector in Poland and the Baltic States intensified to the same level as in Denmark the increase in nutrient loads was even more substantial than in our calculations. The phosphorus load to the Baltic proper doubled and nitrogen loads increased with $70 \%$. The consequences of ERA Scenario 1, where all agriculture in the Baltic drainage area is converted according to ERA in each country, would be very different. Calculations indicate a decrease of the nitrogen surplus with $47 \%$, see Fig. 4. In ERA 2 all agricultural production in the studied countries is converted to the more efficient ERA practiced in Sweden. In this scenario nitrogen surplus decreased even more, with 61\%, compared to today's situation. In both ERA scenarios the phosphorus surplus would be negative and would thus result in a significant decrease of the phosphorus load to the Baltic Sea.

The total annual output of crop and animal production in kilotons nitrogen has been calculated for the scenarios (Fig. 5). The conventional scenario (Conv. Scen.), would give an increased crop production of about $30 \%$ and increased animal production of about 40\%. ERA 1 resulted in $15 \%$ lower crop production and $40 \%$ lower animal production. The lower output is explained by a very extensive production with low productivity on ERA farms in the Baltic countries and Poland. On the other hand, ERA scenario 2 would give almost the same production of crop and animal products as the present average agriculture but with a reduced surplus of nitrogen on farm and field level and no surplus of phosphorus. This scenario requires that the relative high productivity of Swedish ERA-farms is introduced in Poland and the Baltic States. Thus, Swedish ERA is less productive per hectare than conventional Swedish agriculture but more productive than the average production in Poland and the Baltic States.

\section{Discussion}

An overall reduction of the concentration of nutrients in the Baltic Sea close to natural levels is one of the nationally (Ministry of Environment, 2007) and internationally (HELCOM, 2007) agreed environmental goals for the Baltic Sea Region. Some progress has been made but despite this the state of the Baltic Sea has not improved and further efforts are needed (The Swedish Environmental Advisory Council, 2005, p. 31). Reaching the goal implies different strategies for the different countries. In countries with nutrient intensive agriculture like Sweden, Finland and Denmark loads have to be decreased. Sweden and Finland are the two states that are furthest away from achieving their obligations (SOU, 2003). In countries with nutrient extensive agriculture like Estonia, Latvia and Lithuania the agriculture sector needs to develop without increasing the surplus of nutrients.

\subsection{Effects on Emissions in Different Governance Regimes}

Field experiments show reduced losses of nutrients due to changed plowing practices, in-sowing catch crops, practicing spring plowing only 


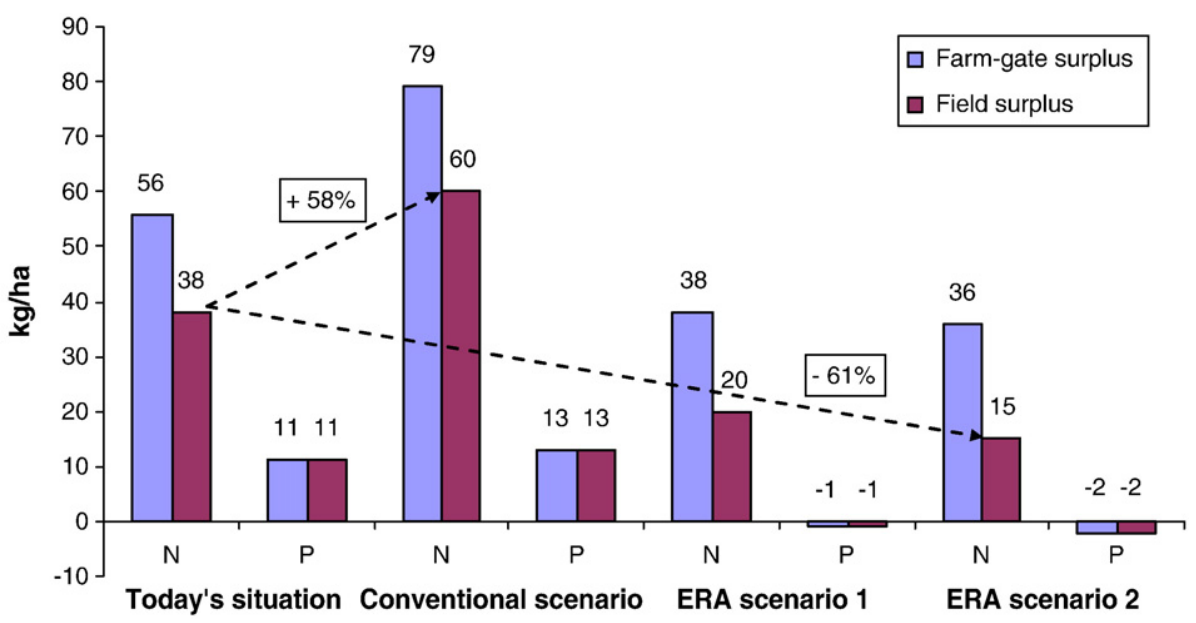

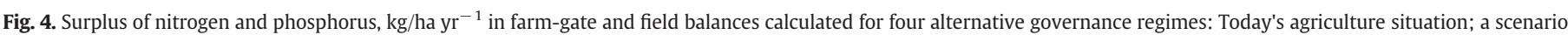
where agriculture in Poland and the Baltic countries is converted to conventional agriculture similar to agriculture in Sweden (Conventional scenario); all agriculture in the Baltic Sea drainage area is converted to Ecological Recycling Agriculture as practiced in the respective countries (ERA Scenario 1); all agriculture is converted to ERA as practiced in Sweden (ERA Scenario 2).

and applying of manure only during spring. These results have been used in models to calculate the decrease in losses of plant nutrients in different combination of management (Larsson et al., 2005a). But this will only have a temporary effect if not accompanied with a change in animal density and/or a more efficient use of manure in combination with a reduced use of artificial fertilizers. If not the biological system will established a new equilibrium between immobilization and mobilization of nitrogen (Jansson and Persson, 1982) and the surplus of nutrients will accumulate and finally result in nutrient losses (Granstedt, 2000).

According to SEPA and the Swedish Board of Agriculture it will prove difficult to fulfil Sweden's obligations in terms of reducing nutrient emissions. To come close to the HELCOM targets far reaching, costly and unrealistic measures would be needed (SEPA, 2008). In the SEPA scenarios presented in Table 5 agricultural production in southern Sweden is reduced. This measure is the only one that can match reductions achieved under an ERA regime.

Swedish agriculture leaches some 22,000 tons of nitrogen per annum to the Baltic Sea (SEPA, 2008). A large scale conversion to ERA would result in reductions of $15,100-16,100$ tons, depending on if 70 or $75 \%$ reduction is achieved compared with conventional agriculture. Phosphorous emissions are reduced with $100 \%$ which corresponds to

\section{Crop and animal output production (total kt $\mathrm{N}$ )}

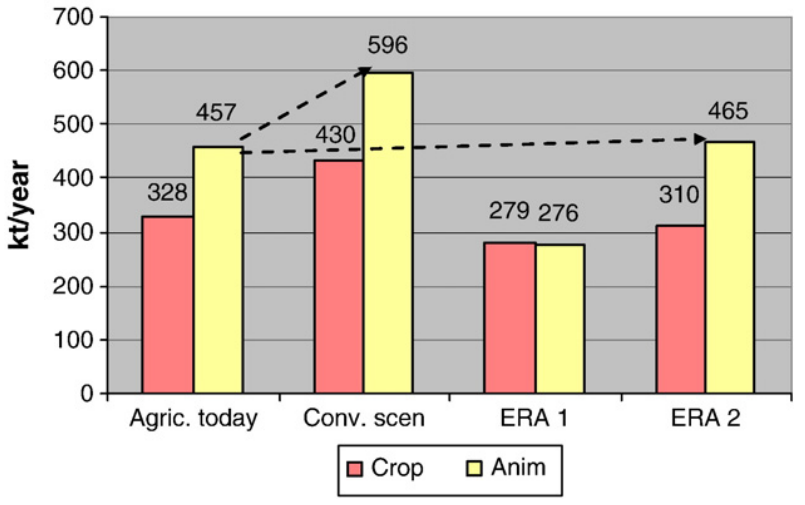

Fig. 5. Crop and animal production in the conventional scenario and two alternative ERA scenarios would result in an increase, reduced and unchanged agricultural production respectively, compared with today's average (based on data from Granstedt, 2005). In the conventional scenario, agricultural techniques used in Sweden are implemented in all Baltic Sea agriculture. In ERA 1, ERA techniques and productivity rates of each country are implemented throughout the respective countries. In ERA 2, Swedish ERA techniques and productivity rates are implemented in all Baltic Sea agriculture. a reduced load of 210 tons. Few other measures demonstrate as high reductions in nutrient loads.

Today, Poland and the Baltic States show relative low surplus/ emissions of nutrients accompanied with a rather modest output of food. The access to EU subsidies and the internal market most likely will alter the rural economies in these countries (HELCOM, 2005). If conventional industrial production techniques, similar to the ones in use in Sweden and Finland, are chosen emissions of nitrogen and phosphorus are expected to increase significantly (Figs. 4 and 5; HELCOM, 2007). This increase might be more than the already stressed ecosystem can cope with (The Swedish Environmental Advisory Council, 2005).

\subsection{Effects on Production}

Following the conventional scenario where Poland and the Baltic States alter their production according to mainly industrial agriculture production will increase, see Fig. 5. The large difference between the ERA 1 (based on today's harvests on the 42 ERA farms studied) and ERA 2 (based on results from 12 Swedish farms) scenarios illustrates the production gain that can be made if local organic agriculture in Poland and the Baltic States introduce production methods practiced in Sweden. Following this, a large scale conversion to ERA does not have to result in lower production. The ERA 2 scenario suggests that the production figures for the region would remain basically the same as today. Since the harvest levels of Swedish ERA farms are higher than the present harvest in Poland and the Baltic States the total output would actually increase while emissions of nutrients would decrease should only Poland and the Baltic States convert their agriculture of today to an efficient ERA-production.

Table 5

Effects from three hypothetical Swedish Environmental Protection Agency scenarios with reduced Swedish agriculture. In Scenario 1, 230,000 ha of productive land in coastal zones in southern Sweden is turned into fallow. In Scenarios 2 and 3 the acreage increases to 375,000 and 940,000 ha. Source: SEPA 2008.

\begin{tabular}{|c|c|c|c|c|}
\hline $\begin{array}{l}\text { Scenario } \\
\text { (SEPA) }\end{array}$ & $\begin{array}{l}\text { Acreage in fallow } \\
\text { in coastal zones }\end{array}$ & $\begin{array}{l}\text { Reduced emissions } \\
\text { to the Baltic Sea }\end{array}$ & $\begin{array}{l}\text { Estimated } \\
\text { cost } / \mathrm{kg}\end{array}$ & $\begin{array}{l}\text { Reduced } \\
\text { employment }\end{array}$ \\
\hline Scenario 1 & 230,000 ha & 3000 ton $\mathrm{N}$ & 317-566* SEK & 5000 \\
\hline Scenario 2 & 375,000 ha & 5000 ton $\mathrm{N}$ & 251-470* SEK & 9000 \\
\hline Scenario 3 & 940,000 ha & 8500 ton $\mathrm{N}$ & $325-628 *$ SEK & 19,000 \\
\hline
\end{tabular}

*Depending of future price levels of crop. 
The effect on Swedish food production of the three scenarios from SEPA is presented in Table 6. Since much of the affected acreage is in highly productive areas the effect is substantial. In Scenario 2 the production of several crops more or less reduced by half and in Scenario 3 large parts of production has ceased. Animal production is also expected to change according to the reduced crop production. This is due to both increased costs for fodder and reduced possibilities to spread manure. In comparison, a large scale introduction of ERA in Sweden show low production losses but high reductions in emissions. Assuming that the recycling principles of ERA are followed animal production needs to be decreased in the southern parts of Sweden, while a corresponding increase is required in central Sweden, see Fig. 2a. A transition from conventional to ERA production in Sweden would reduce nitrogen leaching with $70-75 \%$ and reduce animal production with $22 \%$ and vegetable production with $28 \%$. Phosphorous surplus is reduced in all.

\subsection{Effects on Income, Prices and Employment}

Three different studies of economic aspects of ERA, carried out in the BERAS project, indicate that benefits outweigh costs at firm level but that consumers face increased prices. When asked about how producers perceived their economic situation most replied that it was satisfying in a Swedish study of local organic producers (Larsson et al., 2005b). None reported to suffer from economic stress and organic production was often stated to be at least as profitable as conventional production. Production costs were higher and yields lower but this was compensated for by the price premium received. An example of this is reported in a BERAS-study of costs for milk production (Reeder, 2005). Of the production studied half was sold as organic milk to Arla, the dominant Swedish diary, with a price premium of SEK0.5/kg compared to conventional milk and half of the production was sold to a local diary paying an extra SEK0.5/kg premium for Demeter certified milk, which ERA produced milk qualify as. To this is added an EU subsidy under the CAP programme paid to organic producers. All in all profitability was higher in ERA than in conventional milk production.

The lower yields in ERA production and the higher retail prices are mirrored in consumer prices. A household survey carried out in the BERAS project (Hannula and Thomsson, 2005) found that a food basket with a high share of organic as well as local and organic products was $17 \%$ more expensive than an average Swedish food basket. The share of organic food was $73 \%$ compared to $2.2 \%$ in an average Swedish food basket. 33\% turned out to be local and organic. Comparable figures for an average Swedish food basket are lacking but it is assumed that they are very low.

The effects on employment in an ERA like strategy where production is localized and turned organic show different signs at local and national levels according to a Finnish study (Helenius et al., 2007). Opportunities for local employment increased with $6 \%$ if all possible demand was localized with conventional agricultural production and present consumption patterns. In a scenario with localized organic production local employment increased with $8 \%$. At national level however, localization resulted in a $0.2 \%$ decrease in employment opportunities. The effects of SEPA's scenarios were more negative and locally they could prove severe. SEPA's Scenarios 1, 2 and 3 reduce employment in

Table 6

Production losses (\%) compared to 2007 under different SEPA scenarios. Source: SEPA, 2008.

\begin{tabular}{|c|c|c|c|c|c|c|c|}
\hline \multicolumn{4}{|c|}{ Animal production } & \multicolumn{4}{|c|}{ Vegetable production } \\
\hline Scenario & Sow & Hog & Poultry & Cereals & Oil plants & Potatoes & Sugar beet \\
\hline Scenario 1 & $24 \%$ & $26 \%$ & $20 \%$ & $23 \%$ & $26 \%$ & $31 \%$ & $75 \%$ \\
\hline Scenario 2 & $44 \%$ & $46 \%$ & $37 \%$ & $34 \%$ & $41 \%$ & $52 \%$ & $99 \%$ \\
\hline Scenario 3 & $80 \%$ & $37 \%$ & $75 \%$ & $89 \%$ & $95 \%$ & $85 \%$ & $99 \%$ \\
\hline
\end{tabular}

agriculture with 5000, 9000 and 19,000 full time equivalents respectively, see Table 5. A full time worker in agriculture generates one full time equivalent worth of work in service and processing. A rough estimate would thus double the number of job opportunities lost. The figures can be regarded as conservative since milk and beef production is unaccounted for (SEPA, 2008). Considering that close to 60,000 are employed in Swedish agriculture and approximately the same number work in the processing industries the loss is considerable.

\subsection{Reduction Costs}

The cost per reduced $\mathrm{kg}$ of nutrient is dependent on several factors including global demand for food and bio-energy, implementation time and the extent of measures taken. A lot of capital is bound to present production and the cost will increase with shorter implementation time. The larger the restructure in the agricultural sector the more difficult for other sectors to absorb labour and other factors of production. Finally, the precision is important. If a measure can be aimed at areas with low productivity but high leaching to the Baltic Sea or if affected lands can be used for alternative production, e.g. ERA, costs will be reduced.

The dominant costs for implementing ERA in Sweden and other old EU member states are probably in the form of farm level infrastructure investments, lower yields and to some extent for training and extension services. No estimates of social costs for a large scale conversion towards localized organic production have been calculated. A conversion might cost more than is saved. This question is beyond the scope of this paper. There are however estimates of other reduction measures, including the SEPA scenarios, which can serve as benchmarks. Gren (2001) identifies three main ingredients in a cost efficient mix of measures to reduce nitrogen emissions: measures aimed at agriculture; extending the capacities of municipal waste water treatment plants, and the (re-)creation of wetlands as nitrogen traps. Turner et al. (1999, p. 345) quantify the marginal costs for these measures for different countries. Today several reduction measures have been implemented. This has increased the estimated reduction costs of additional measures. The marginal cost of one $\mathrm{kg}$ nitrogen reduction in agriculture was according to Turner et al. SEK22-42 whereas recent estimates by SEPA and the Swedish Board of Agriculture are substantially higher, see Table 7.

For water treatment there is still some low hanging fruit where nitrogen reduction can be achieved at a cost of SEK10-190/ $\mathrm{kg}$ but the amount of potential reduction is small. Additional measures, corresponding to 900 tons, are suggested (see Table 7) but much of the improvements in Swedish point-sources are already done. Swedish

Table 7

Examples of measures, costs and effects for Sweden (SEPA, 2008).

\begin{tabular}{lll}
\hline Agriculture & $\begin{array}{l}\text { Reduced emissions } \\
\text { to the Baltic Sea }\end{array}$ & Estimated cost $/ \mathrm{kg}$ \\
\hline "Catch the nutrients"a & 120 ton $\mathrm{N}$ & No data \\
Catch crops + spring cultivation & 300 ton $\mathrm{N}$ & $333 \mathrm{SEK} / \mathrm{kg} \mathrm{N}$ \\
$\begin{array}{l}\text { Restricted spreading of manure } \\
\text { Wetlands, } 6000 \text { ha }^{\mathrm{b}}\end{array}$ & 100 ton $\mathrm{N}$ & No data \\
Wetlands, addition 6000 ha & 100 ton $\mathrm{N}$ & No data \\
& 500 ton $\mathrm{N}$ & No data \\
Other measures & & \\
Municipal water treatment plants & 900 ton $\mathrm{N}$ & $10-190 \mathrm{SEK} / \mathrm{kg} \mathrm{N}$ \\
Private water treatment & 66 ton $\mathrm{N}$ & $1800-5800 \mathrm{SEK} / \mathrm{kg} \mathrm{N}$ \\
& 25 ton $\mathrm{P}$ & $7500-30,000 \mathrm{SEK} / \mathrm{kg} \mathrm{P}$ \\
Mussel cultivation in coastal zones & 450 ton $\mathrm{N}$ & $36 \mathrm{SEK} / \mathrm{kg} \mathrm{N}$ \\
& 35 ton P & $350 \mathrm{SEK} / \mathrm{kg} \mathrm{P}$ \\
\hline
\end{tabular}

a "Greppa näringen", information and education for a more efficient use of nutrients in conventional agriculture.

b Construction and reconstruction.

c Lower cost range for improvements of already existing facilities. Upper range for new installations. 
phosphorous reduction is $97 \%$ in municipal waste water treatment plants and further measures are not motivated according to SEPA (2008) why other measures become more interesting. One measure reducing both nitrogen and phosphorous is mussel cultivation in coastal zones. The reduction cost is encouraging and if applied at large scale this could be an important measure in the future. Today the lion part of reduction needs to be in agriculture. Out of this, measures aiming for a more efficient conventional agriculture, i.e. the "Catch the nutrients" campaign and restrictive spreading of manure only account for a limited impact.

Elofsson (2003) rank cost efficient measures to reduce the agricultural load of nitrogen and phosphorous to the Baltic Sea. Reductions in the use of chemical fertilizers are by far the most important measure followed by changes in land use, primarily increasing the area for catch crops. A total reduction of chemical fertilizers and changed land use in terms of a less intense production, as prescribed by ERA production, might not be as cost efficient as the measures examined by Elofsson.

Measures identified by SEPA (2008), some of which are listed in Table 7, together account for 7000 and 61 tons of reduced emissions of nitrogen and phosphorous respectively. This is far from the reduction targets of 21000-17000 tons of nitrogen and 290-260 tons of phosphorous, including other sources than agriculture. Not even in combination with SEPA's Scenario 3 the targets could be met.

\section{Cooperation and Policy Instruments - Overcoming the Obstacles}

Reductions in nutrient loads have only been substantial in countries where political and economical changes have lead to a recession in the agriculture sector. In fact, Estonia, Latvia and Russia are the only countries that have reached the emission target set out by HELCOM. Agricultural production is likely to increase again and with them nutrient loads. "These trends will be highly dependent on the future agricultural policies of the EU" (HELCOM, 2004b).

Meanwhile, because of the growing awareness among policymakers that the present policy, implemented in the new EUmembers, is unsustainable and needs to be changed, the expansion of the EU can be viewed as a policy window (Kingdon, 1995) or a window of opportunity. On the one hand Poland and the three Baltic States today are regulated by EU environmental legislation. On the other hand they have access to funding through CAP. The window of opportunity enables decision makers to steer agricultural production down an efficient but yet environmentally friendly route. If this opportunity is not taken now there is a risk that the agricultural sector is modernized in a resource intensive and, from the perspective of the Baltic Sea environment, less desired direction.

A range of different policy instruments involving regulations and incentives are at hand. Few are directed directly towards ERA. Indirectly, several are. Lankoski and Ollikainen (2003) as well as Vatn et al. (1997) conclude that increased taxation on fertilizers together with a subsidy for changed land use is a cost efficient way to reduce nutrient runoff from agriculture. Edman (SOU, 2005) suggests increased public procurement of local organic food to stimulate a sustainable agriculture. Both these suggestions could favour ERA. Tradable emission permits with non-point source pollutions including nutrients are rejected by Collentine (2002). However, one solution, which also would favour ERA, could be to introduce tradable permits for animal production, for spreading manure or for mineral fertilizers. Animal density could be adjusted to acreage in such a way that the nutrient content in the manure produced don't exceed the need of vegetables produced (Alkan-Olsson, 2004). A producer with plenty of animals could buy spreading permits for manure from a neighbouring farm.

It has been shown that all countries would benefit from participating in an effort to combat eutrophication of the Baltic Sea (Gren and Folmer, 2003; Gren, 2001). Similar results are presented by
Elofsson (2007). She argues that unilateral action is highly uncertain and could prove costly, compared to bilateral measures. The benefits of cooperation are evident in our study as well. Major production gains can be achieved if new EU-members learn from Swedish agriculture, whether they modernize their production in the direction towards ERA or conventional agriculture. One obstacle that has to be solved is on land available for food production. Swedish agriculture today depends on large input of fodder (Deutsch, 2004) and fertilizers. In a unilateral, large scale, implementation of ERA Sweden might need to import some food due to a lack of arable land instead of importing fodder and fertilizers. Developing an agricultural policy towards more ERA-like agriculture, especially in Poland and the Baltic States, is a way to combat eutrophication in the Baltic Sea. This can be achieved without a fall in production if regional cooperation is established following ERA 2. In the words of HELCOM (2005, p. 15) "in order to combat eutrophication (especially in the open sea), nutrient reduction measures should be considered jointly for the whole Baltic Sea region".

\section{Conclusion - Governing the Agriculture and the Baltic Sea}

The expansion of the EU with new member states is a window of opportunity. The Polish, Estonian, Latvian and Lithuanian agricultural sectors will be restructured as a consequence of their entrance into the EU. An effective governance of the agricultural sector could very well be coherent with a sustainable governance of the Baltic Sea. A large scale conversion of agricultural production into ERA methods, using existing local production techniques and productivity rates, in the eight EU countries around the Baltic Sea reduced nitrogen surplus with almost 50\% and eliminated phosphorus surplus in all. Crop output dropped with $15 \%$ and animal production with $40 \%$. Were the efficient ERA production that is in use in Sweden today to be introduced in all EU countries around the Baltic Sea the aggregate crop production would marginally decrease and animal production increase compared to today's levels. In this scenario nitrogen surplus decreased with over $60 \%$. The effect in terms of reduced leaching to the Baltic Sea was even higher.

On the other hand, if the new EU-members develop in the direction of Swedish or Finnish agriculture the surplus of nitrogen and phosphorus risk increase considerable, nitrogen with $58 \%$ and phosphorus with $18 \%$. These estimates are conservative compared to similar ones presented by HELCOM (2007). In our scenario crop production would increase with approximately $30 \%$ and animal production with $40 \%$.

Agriculture is the main source of nutrients to the Baltic Sea and eutrophication is, according to HELCOM, the main threat to the Baltic Sea environment. According to SEPA it will prove hard to fulfil Sweden's reduction targets. Changing today's conventional farming system towards the low input recycling system of ERA provides one possibility. Further research is however needed to calculate the full cost of this. The contracting parties of HELCOM, including the Swedish government, have incentives to use the window of opportunity before it is closed. In the words of Kingdon (1995, p. 170) one should "strike while the iron is hot". For a maximum, cost-efficient, effect this "strike" should be coordinated internationally.

\section{Acknowledgments}

We like to thank two anonymous reviewers and Thomas Hahn for valuable comments and Wijnand Koker for technical assistance.

\section{References}

Alkan-Olsson, J., 2004. Alternative economic instruments of control. In: Lundqvist, L., Jonsson, A., Galaz, V., Löwgren, M., Alkan-Olsson, J. (Eds.), Sustainable Water Management: Organisation, Participation, Influence, Economy. VASTRA Report 5. Gothenburg University (In Swedish). 
Boesch, D., Hecky, R., O'Melina, C., Schindler, D., Seitzinger, S., 2006. Eutrophication of Swedish Seas, Report 5509. Swedish Environmental Protection Agency, Stockholm. Brandt, M., Ejhed, H., 2002. TRK Transport-Retention-Källfördelning, Report 5247. Swedish Environmental Protection Agency, Stockholm.

Brink, N., 1990. Land Use Changes in Europe. Process of Change, Environmental Transformation and Future Patterns. In: Brower, M. (Ed.), Kluwer Academic Publishers, London.

Brusendorff, A.C., 2007. 2nd Stakeholder Conference on the HELCOM Baltic Sea Action Plan. . http://www.helcom.fi/BSAP/2nd/en_GB/2nd_Stakeholder_Conf/.

Cederberg, C., Flysjö, A., 2004. Life Cycle Inventory of 23 Dairy Farms in South-west Sweden. SIK-Report 728. SIK - Institutet för Livsmedel och Bioteknik, Göteborg, Sweden.

Collentine, D., 2002. Search for the northwest passage: the assignation of NSP (nonpoint source pollution) rights in nutrient trading programs. Water science and Thechnology 45 (9), 227-234.

Dalgaard, R., Halberg, N., Kristensen, I.S., Larsen, I., 2006. Modelling representative and coherent Danish farm types based on farm accountancy data for use in environment assessments. Agriculture, Ecosystems \& Environment 4, 222-237.

Deutsch, L., 2004. Global trade, food production and ecosystem support: Making the interactions visible. Doctoral thesis, Stockholm University, Stockholm.

Diaz, R.J., Rosenberg, R., 2008. Spreading dead zones and consequences for marine ecosystems. Science 321, 926-929.

Elofsson, K., 2003. Cost-effective reductions of stochastic agricultural loads to the Baltic Sea. Ecological Economics 47, 13-31.

Elofsson, K., 2007. Cost uncertainty and unilateral abatement. Environmental and Resource Economics 36 (2), 143-162.

Folke, C., 2006. Resilience: the emergence of a perspective for social-ecological systems analyses. Global Environmental Change 16 (3), 253-267.

Geier, U., Köpke, U., 1998. Comparison of conventional and organic farming by processlife cycle assessment. A case study of agriculture in Hamburg. Proceedings of the International Conference on Life Cycle Assessment in Agriculture, Agro-industry and Forestry. Brussels, Belgium, pp. 31-38

Granstedt, A., 1995. Studies on the flow supply and losses of nitrogen and other plant nutrients in conventional and ecological agricultural systems in Sweden. Biological Agriculture and Horticulture 11, 51-67.

Granstedt, A., 2000. Increasing the efficiency of plant nutrient recycling within the agricultural system as a way of reducing the load to the environment - experience from Sweden and Finland. Agriculture, Ecosystems and Environment 80.

Granstedt, A., 2005. Results of plant nutrient balances in the BERAS countries. Concluding results and discussions. In: Granstedt, A., Thomsson, O., Schneider, T.(Eds.).

Granstedt, A., Seuri, P., Thomsson, O., 2004. Effective recycling agriculture around the Baltic Sea. Ekologiskt Landtbruk, 41. The Swedish University of Agricultural Sciences, Uppsala.

Granstedt, A., Seuri, P., Thomsson, O., 2008. Ecological recycling agriculture to reduce nutrient pollution to the Baltic Sea. Journal of Biological Agriculture and Horticulture vol. 26, 279-307.

Gren, I.-M., 2001. International versus national actions against nitrogen pollution of the Baltic Sea. Environment and Resource Economics vol. 20, 41-59.

Gren, I.-M., Folmer, H., 2003. Cooperation with respect to cleaning of an international water body with stochastic environmental damage: the case of the Baltic Sea. Ecological Economics 47, 33-42.

Halberg, N., Kristensen, I.S., Dalgaard, T., 2000. Linking data sources and models at the level of processes, farm types and regions. In: Weidema, B., Meeusen, M.G.J. (Eds.), Agricultural Data for Life Cycle Assessments, vol 1. LEI, The Hague, pp. 16-30.

Hannula, A., Thomsson, O., 2005. Consumer surveys in Juva and Järna for identification of eco-local food baskets. In: Gransted, A., Thomsson, O., Schneider, T. (Eds.), Environmental impacts of eco-local food systems - final report from BERAS Work Package 2. The Swedish University of Agricultural Sciences, Uppsala.

HELCOM, 2003a. The Baltic Marine Environment 1999-2002. Baltic Sea Environment Proceedings No. 87, Helsinki.

HELCOM, 2003b. Executive Summary of the Fourth Baltic Sea Pollution Load Compilation. (PLC-4), Helsinki.

HELCOM, 2004a. The Fourth Baltic Sea Pollution Load Compilation (PLC-4). Helsinki Commission, Baltic Marine Environment Protection Commission, Baltic Sea Environment Proceedings No. 93, Helsinki.

HELCOM, 2004b. 30 Years of Protecting the Baltic Sea - HELCOM 1974-2004, Helsinki.
HELCOM, 2005. Nutrient Pollution to the Baltic Sea in 2000. Baltic Sea Environment Proceedings No. 100, Helsinki.

HELCOM, 2007. 2nd Stakeholder Conference on the HELCOM Baltic Sea Action Plan. Helsinki Finland, 6 March 2007. Towards a Baltic Sea Unaffected by Eutrophication. Draft.

Helenius, J., Aro-Heinilä, E., Hietala, R., Mikkola, M., Risku-Norja, H., Seppänen, L Sinkkonen, M., Vihma, A., 2007. Systems frame for multidisciplinary study on sustainability of localizing food. Progress in Industrial Ecology 4-5, 328-347.

Jansson, S.L., Persson, J., 1982. Mineralization and immobilization of soil nitrogen. In: Stevenson, F.J., Bremner, J.M., Hauck, R.D., Keeny, D.R. (Eds.), Nitrogen in Agricultural Soils, 22. ASA, CSSA, SSSA, Madison, Wisconsin, U.S.A, pp. 229-252.

Kingdon, J.W., 1995. Agendas, Alternatives, and Public Policies. Harper Collins College, New York.

Kristensen, I.S., 2002. Principles and Methods for Collecting and Evaluation Nutrient Balances. Danish Institute of Agricultural Science. Lithuanian Dairy Farms Demonstration Project, pp. 29-40. htpp://www.agrsci.dk/jbs/demolit/Principles\% 20methods.pdf.

Kristensen, I.S., Halberg, N., Nilsen, A.H., Dalgaard, R., 2005. Denmark Part II. N-turnover on Danish mixed dairy farms. In: Bos, J., Pfilimin, A., Aarts, F., Dalgaard, R., Vertès, F. (Eds.), Nutrient Management at Farm Scale. How to Attain Policy Objectives in Regions with Intensive Dairy Farming? First Workshop of the EGF Working Group 'Dairy Farming Systems and Environment' Quimper, France, 23-25 June 2003. Plants Research, PRI Report, 83, pp. 91-109.

Lankoski, J., Ollikainen, M., 2003. Agri-environmental externalities: a framework for designing targeted policies. European Review of Agricultural Economics 30 (1), $51-75$.

Larsson, M.H., Kyllmar, K., Jonasson, L., Johnsson, H., 2005a. Estimating reduction of nitrate leaching from arable land and the related costs. AMBIO 34, 538-543.

Larsson, M., Andersson, E., Enberg, S., 2005b. Trust and resilience - a case study of environmental entrepreneurs in Järna. In: Sumelius, J., Vesala, K.M. (Eds.), Approaches to Social Sustainability in Alternative Food Systems, 47. Ekologiskt Lantbruk.

Ministry of Environment, 2007. The Swedish Government's Environmental Goals are Found at www regeringen se, Ministry of Environment and Ministry of Agriculture.

Payraudeau, S., van der Werf, H.M.G., 2005. Environmental impact assessment for a farming region: a review of methods. Agriculture, Ecosystems and Environment $107,1-19$.

Reeder, H., 2005. Production cost of organic milk. A case study of a dairy farm in Sweden. In: Sumelius, J. (Ed.), Possibilities for and Economic Consequences of Switching to Local Ecological Recycling Agriculture. Ekologiskt lantbruk nr 43, The Swedish University of Agricultural Sciences, Uppsala.

SCB, 2003a. Nitrogen and Phosphorus Balances for Arable Land and Agricultural Sector in Sweden, 2001: Statistiska meddelanden MI 40 SM 031Statistics Sweden, Stockholm.

SCB, 2003b. Yearbooks of Agricultural Statistics. Statistics Sweden, Örebro.

SEPA, 2008. Sweden's Obligations in the Baltic Sea Action Plan. Rapport 5830. Swedish Environmental Protection Agency, Stockholm (In Swedish).

SOU, 2003. Havet - tid för en ny strategi. Havsmiljökommissionens betänkande. (In Swedish). SOU 2003:72.

SOU, 2005. Bilen, Biffen, Bostaden. Hållbara laster - smartare konsumtion. (In Swedish) SOU 2005:51.

Steinshamn, H., Thuen, E., Bleken Brenøe, M.A., Ekerholt, G., Cecilie, Y., 2004. Utilization of nitrogen $(\mathrm{N})$ and phosphorus $(\mathrm{P})$ in an organic dairy farming system. Agriculture, Ecosystems \& Environment 104, 509-522.

The Swedish Environmental Advisory Council/Miljövårdsberedningen, 2005. Strategi för hav och kust utan övergödning. Promemoria 2005:1, Miljö- och samhällsbyggnads-departementet, Stockholm.

Turner, R.K., Georgiou, S., Gren, I.-M., Wulff, F., Barrett, S., Söderqvist, T., Bateman, I.J., Folke, C., Langaas, S., Zylicz, T., Markowska, A., 1999. Managing nutrient fluxes and pollution in the Baltic Sea: an interdisciplinary simulation study. Ecological Economics 30, 333-352.

Vatn, A., Bakken, L.R., Romsted, E., Rörstad, P.K., Vold, A., Botterweg, P., 1997. Regulating nonpoint-source pollution from agriculture: an integrated modelling analysis. European Review of Agricultural Economics 24 (4), 514-525. 